\title{
Transoral needle procedures for upper cervical spine and clival lesions: technical note and indications
}

\author{
Horacio Armando Marenco ${ }^{1,2}$, Andrei Fernandes Joaquim', \\ João Flávio Daniel Zullo', Marcelo Luis Mudo ${ }^{2,3}$ \\ Sociedade Beneficente Säo Camilo, Santa Casa de Itu, Hospital Regional de Sorocaba.
}

\begin{abstract}
Transoral needle procedures are minimally invasive techniques derived from the transoral (or transoropharyngeal) approach to the upper cervical spine and clival region. They are indicated for diagnostic procedures and vertebroplasty. These techniques are appropriated to access midline pathologies from the lower clivus to the C2-C3 disk. This article describes in a step by step manner, the technique and indications for needle biopsy and vertebroplasty in this region, discussing technical nuances.
\end{abstract}

\section{KEYWORDS}

Transoral procedures. Biopsy. Vertebroplasty. Atlas. Axis. Clivus.

\section{RESUMO alta: indicações e nota técnica nuances técnicas. \\ PALAVRAS-CHAVE \\ Acesso transoral. Biópsia. Vertebroplastia. Atlas. Axis. Clivus.}

Procedimentos percutâneos transorais com agulha para lesões do clivo e da coluna cervical

Procedimentos transorais com agulhas são técnicas minimamente invasivas derivadas do acesso transoral (ou transorofaríngeo), utilizadas para cirurgias da coluna cervical superior e região do clivo. São geralmente indicados para procedimentos diagnósticos ou vertebroplastia, em lesões localizadas na linha média, do clivo inferior até o espaço discal C2-C3. No presente artigo, descrevem-se passo a passo a técnica e as indicações para biópsia de agulha e vertebroplastia nessa região, discutindo

\section{Introduction}

Since its introduction in the early 60ths, the transoral approach has been successfully used by many surgeons, to treat extradural midline lesions from the clivus to the upper cervical spine. , $^{4,9,14,15,22}$ The approach itself is not technically very demanding, but post operatory complications of the surgery involving anterior decompression with or without fusion of the cranio-cervical region are potentially severe and difficult to deal with, particularly cerebral spinal fluid (CSF) fistulas and local infections. ${ }^{9,15}$

Consequently, when it comes to the case of patients requiring only a biopsy or those who have stable pathological fractures (usually metastatic) of the body of $\mathrm{C} 2$, less invasive procedures would be a safer option.
The transoral needle biopsy is a minimally invasive technique derived from the transoral approach, which is a more direct way to access the upper cervical spine than the current anterolateral puncture techniques.

In this article, we present the surgical technique for transoral needle procedures focused in its application for spinal diseases.

\section{Technique}

The patient is placed on a radiotransparent surgical table in supine position, with slight cervical extension.

\footnotetext{
Neurocirurgião do Serviço de Neurocirurgia do Hospital Regional de Sorocaba, SP.

2 Neurocirurgião do Serviço de Neurocirurgia da Santa Casa de Itu, SP. Sociedade Beneficente São Camilo.

3 Coordenador do Serviço de Neurocirurgia do Hospital Regional de Sorocaba, SP.
} 
The head is placed over a donnut or radiotransparent head support.

The procedure is performed under general anesthesia with orotraqueal or nasotraqueal intubation, ${ }^{11}$ unless the patient already has a traqueostomy, which will then be used.

Then, the oral cavity is exposed with mouth gag. The McIvor retractor suits very well for this procedure and it is simple and easy to use (Figure 1).

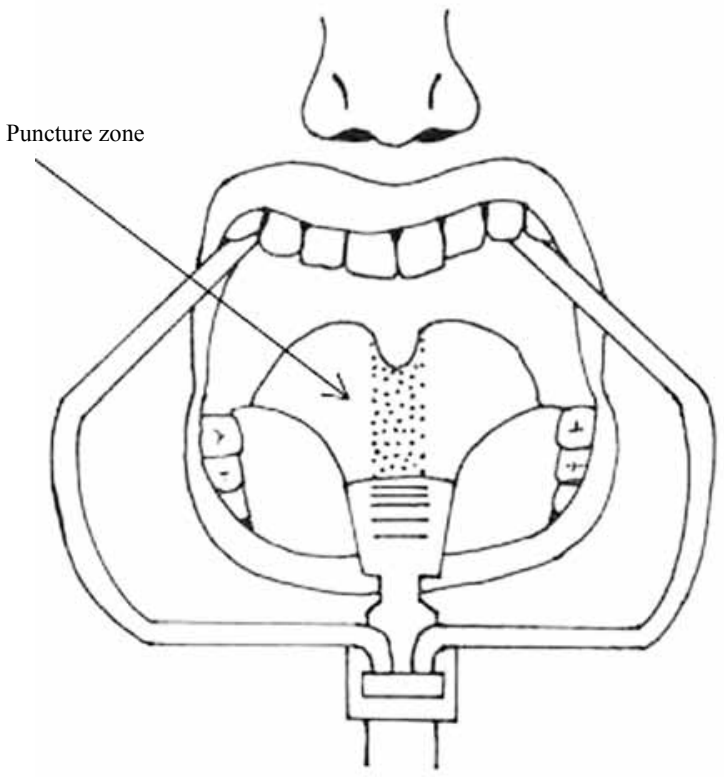

Figure 1-A schematic representation of McIvor mouth retractor and the puncture zone.

The oral cavity is a colonized area, thus careful disinfection must precede the procedure. For this purpose we use clorexidine aquous solution. Also, the patient must receive proper intravenous antibiotic prophylaxis according to the institution's profile. It is advisable to occlude the laryngopharynx with a gauze pack. In the presence of local infection or severe periodontal disease, the procedure should be postponed until it is resolved.

The $\mathrm{C}$-arm is positioned over the head of the patient, perpendicular to the surgical table to obtain an antero-posterior (AP) image. At this point, the image should present the lateral masses of $\mathrm{C} 1$, the body and odontoid process of $\mathrm{C} 2$, and the $\mathrm{C} 2-\mathrm{C} 3$ disk space. Also the surgeon must check that the head of the patient is correctly aligned and the midline structures, such as the odontoid process, are well centered in the fluoroscopy image.

The midline oropharyngeal mucosa is then infiltrated with $1 \%$ lydocaine with adrenaline. After that, a 12 or 14 gauge biopsy needle is inserted in the midline, perpendicular to anterior longitudinal ligament plane and slowly advanced a few millimeters. Another AP image is obtained and, the correct positioning of the needle is checked (Figure 2). Then, the $\mathrm{C}$-arm is rotated
90 degrees and a lateral image is obtained. Once again the position of the needle is checked (Figure 3). Under fluoroscopy guidance in the lateral view, the needle is advanced to the desired depth, always taking care to do not violate the spinal canal.

If a biopsy is the purpose of the procedure, a $20 \mathrm{ml}$ syringe is connected to the needle exerting negative pressure to obtain a tissue sample.

The same technique is used if the procedure is a vertebroplasty. A special vertebroplasty needle is used instead. After adequate needle positioning, under continuous lateral fluoroscopy control, an osseous venography is obtained by injecting non ionic contrast media. If direct filling of the basivertebral veins is noted, the needle is repositioned and osseous venography is repeated. Then, 1 to $3 \mathrm{ml}$ of polymethylmethacrylate are injected into the body of $\mathrm{C} 2$, under continuous fluoroscopic control.

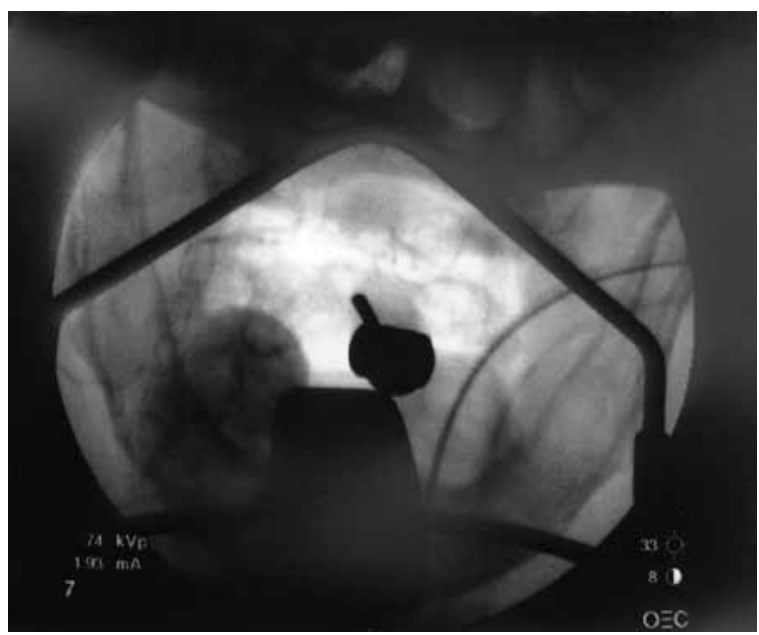

Figure 2-AP intraoperative fluoroscopy view during the procedure. The needle is positioned in the body of $\mathrm{C} 2$, in the midline.

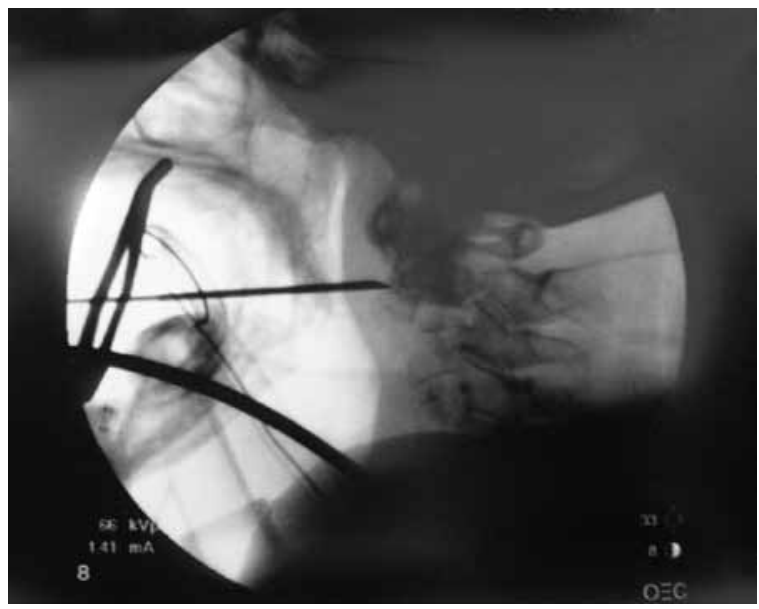

Figure 3 - Lateral intraoperative fluoroscopy view of the needle insertion in the body of $C 2$. 
Usually, there is no need for any special procedure for hemosthasis at the puncture site. If bleeding is present, it can be controled with a stherile gauze and gentle pressure over the puncture site, or a stitch.

\section{Discussion}

The transoral approach is currently used to operate anterior lesions of the upper cervical spine. Some authors ${ }^{2,4}$ quoted Fang and Ong as the responsible for establishing this operative approach in 1962. Since then, large series of patients and modifications of the technique were published and the advantages and risks of the transoral surgery are now well understood. ${ }^{2,49,14,15,22}$

One of the main advantages of this approach is that the midline of the pharynx over the upper cervical spine is relatively avascular, and there are virtually no important structures between de pharynx mucosa and the vertebrae. These anatomical features make the transoral approach very direct and particularly safe for percutaneous procedures of the upper cervical spine.

Many patients are referred to spine surgeons for the evaluation of cervical spine lesions that are of unknown nature. Often, these patients have neither neurological symptoms nor signs of spinal instability, which urges the need of a biopsy prior to a definitive treatment into perspective.

There are different conditions that may affect the clival and anterior atlantoaxial regions, which are not always easy to distinguish with current imaging techniques. These are of neoplastic, inflammatory or infectious origin.

Treatment for these conditions may require surgery for decompression and stabilization of the upper cervical spine. Then, a tissue sample is obtained during the surgery.

However, in some cases, there is no evidence of neural structures compression or spinal instability, or the patient is in a poor clinical condition for surgery. Then, the possibility to obtain a biopsy with a minimally invasive and low morbidity procedure is important for planning the treatment. The transoral technique is ideal for a needle biopsy in these cases.

Vertebroplasty for spine fractures has been gaining popularity and, there is a considerable number of studies with large series of patients treated for pathological vertebral fractures. $3,5,7,8,10,12,13,19$ Despite the fact that percutaneous vertebroplasty was first attempted in the cervical spine, ${ }^{7}$ there are only a few studies about $\mathrm{C} 2$ vertebroplasty or kyphoplasty. ${ }^{1,6,7,16-18,20,21}$

Although a rare site for metastasis, cancer patients may present with pathologic fractures of the body of $\mathrm{C} 2$.
These are currently treated either with surgery or with a cervical orthosis and radiotherapy. The patients selected for non operative treatment have to be immobilized for long periods and still may fail to achieve pain relief. In these cases, vertebroplasty or even kyphoplasty are reasonable treatment options. . $^{1,6,16-18,20,21}$

This kind of treatment has been used for pathologic fractures of the body of $\mathrm{C} 2$ caused by tumors, specifically when the patient has neck pain, minimal or no neurological deficit or has already failed non operative treatment.

\section{Conclusion}

The technique for transoral needle procedures presented in this article is simple and minimally invasive. It allows the surgeon to effectively obtain tissue samples of the lower clivus and anterior $\mathrm{C} 1-\mathrm{C} 2$ to $\mathrm{C} 3$, allowing adequate treatment planning.

It is also appropriated for $\mathrm{C} 2$ body vertebroplasty or kyphoplasty, which are novel techniques, to obtain pain control and stabilize pathologic fractures of the body of $\mathrm{C} 2$.

\section{References}

1. Anselmetti GC, Regge D, Sardo E, Manca A, Cirillo $\mathrm{S}$, Meloni $\mathrm{T}$, et al. Minimally invasive treatment of $\mathrm{C} 2$ odontoid traumatic fracture with transoral percutaneous vertebroplasty. Eur Radiol. 2007;17:850-1.

2. Bonney G, Williams JPR. Trans-oral approach to the upper cervical spine. J Bone Joint Surg (Br). 1985;67B:691-8.

3. Cortet B, Cotten A, Boutry N, Flipo RM, Duquesnoy B, Chastanet $P$. Percutaneous vertebroplasty in the treatment of osteoporotic vertebral compression fractures: an open prospective study. J Rheumatol. 1999;26:2222-8.

4. Crockard HA. The transoral approach to the base of the brain and upper cervical cord. Ann R Coll Surg Engl. 1985;67:321-5.

5. Deramond H, Depriester C, Galibert P, Le Gars D. Percutaneous vertebroplasty with polymethylmethacrylate: technique, indications, and results. Radiol Clin North Am. 1998;36:533-46.

6. Gabrillarges J, Michel JL. Interventional radiology: transoral approach to C2. J Radiol. 2008;89:245-9.

7. Galibert P, Deramond H, Rosat P, LeGars D. Preliminary note on the treatment of vertebral angioma by percutaneous acrylic vertebroplasty [in French]. Neurochirurgie. 1987;33:166-8.

8. Jensen ME, Kallmes DE. Percutaneous vertebroplasty in the treatment of malignant spine disease. Cancer $\mathrm{J}$. 2002;8:194-206. 
9. Landeiro JA, Boechat S, Christoph DH, Gonçalves MB, Castro I, Lapenta MA, et al. Transoral approach to the craniovertebral junction. Arq Neuropsiquiatr. 2007;65:1166-71.

10. Lieberman IH, Dudeney S, Reinhardt MK, Bell G. Initial outcome and efficacy of "kyphoplasty" in the treatment of painful osteoporotic vertebral compression fractures. Spine. 2001;15:1631-8.

11. Marks RJ, Forrester PC, Calder I, Crockard HA. Anaesthesia for transoral craniocervical surgery. Anaesthesia. 1986;41:1049-52.

12. McGraw JK, Cardella J, Barr JD. Society of Interventional Radiology quality improvement guidelines for percutaneous vertebroplasty. J Vasc Interv Radiol. 2003;14(7):827-31.

13. McGraw JK, Lippert JA, Minkus KD. Prospective evaluation of pain relief in 100 patients undergoing percutaneous vertebroplasty: results and follow-up. J Vasc Interv Radiol. 2002;13:883-6.

14. Menezes AH, VanGilder JC. Transoral-transpharyngeal approach to the anterior craniocervical junction. Ten-year experience with 72 patients. J Neurosurg. 1988;69:895-903.

15. Menezes HA. Surgical approaches: postoperative care and complications "transoral-transpalatopharyngeal approach to the craniocervical junction". Childs Nerv Syst. 2008;24:1187-93.

16. Mont'Alverne F, Vallée JN, Cormier E. Percutaneous vertebroplasty for metastatic involvement of the Axis. Am J Neuroradiol. 2005;26:1641-5.
17. Monterumici DA, Narne S, Nena U, Sinigaglia R. Transoral kyphoplasty for tumors in C2. Spine J. 2007;7:666-70.

18. Reddy AS, Hochman M, Loh S, Rachlin J, Li J, Hirsch JA. CT guided direct transoral approach to $\mathrm{C} 2$ for percutaneous vertebroplasty. Pain Physician. 2005;8:235-8.

19. Robinson Y, Tschöke SK, Stahel PF, Kayser R, Heyde CE. Complications and safety aspects of kyphoplasty for osteoporotic vertebral fractures: a prospective follow-up study in 102 consecutive patients. Patient Saf Surg. 2008;2:2-8.

20. Rodriguez-Catarino M, Blimark C, Willén J, Mellqvist UH, Rödjer S. Percutaneous vertebroplasty at C2: case report of a patient with multiple mieloma and a literature review. Eur Spine J. 2007;16:242-9.

21. Sachs DC, Inamasu J, Mendel EE, Guiot BH. Transoral vertebroplasty for renal cell metastasis involving the axis: case report. Spine. 2006;31:925-8.

22. Spetzler RF, Selman WR, Nash CL. Transoral microsurgical odontoid resection and spinal cord monitoring. Spine. 1979;4:506-10.

Endereço para correspondência

Horacio A. Marenco

Rua Candelária, 292

13330-180 - Indaiatuba, SP, Brasil

E-mail: horacio.marenco@gmail.com 